\title{
The Securities Act and the Promoter
}

\section{I}

THE SeCurities ACx of $1933^{1}$ was placed on the statute books by Congress during the flood-tide of the New Deal. Three years have passed. The broad legislative purpose of compelling those who offer new issues of securities to the public to tell the whole truth, and nothing but the truth, is well understood. The Securities and Exchange Commission's methods of compelling full disclosure and for enforcing standards of truth-telling are, however, not as well known. The Act only insists the truth be told. But in deciding when the truth is told, inevitably there is an area of discretion within which procedural methods will produce substantive protection of the investor. The administrative wisdom displayed in the choice of methods of implementing the words of the statute determines the social effectiveness of the legislative experiment.

II

To gauge the effectiveness of this experiment, we must briefly sketch both the general requirements of the Act ${ }^{2}$ and the organization of the Securities and Exchange Commission. The general scheme of the statute is to require that in substantially all cases in which a new issue of securities is to be offered to the public, either in interstate commerce or through the mails, a registration statement must be filed with the Commission. ${ }^{3}$ A prospectus, containing a digest of the registration statement, must be given to all persons to whom the securities are offered for sale. The information contained in these documents is public infor-

148 Stat. (1933-34) Part I, 74, 15 U.S. C.A., § 77a ff. (Supp. 1935). For a discussion of its constitutionality, see (1934) 32 MICE. L. REv. 811. The constitutionality of the Securities Act was challenged in Jones v. Securities and Exchange Comin. (1936) 298 U. S. 1, but the Supreme Court did not pass on that question. For a discussion of the important features of the Act, see James, The Securities Act of 1933 (1934) 32 MrCr. L. REv. 624. This article contains a selected bibliography of the literature on the Securities Act. James, op. cit. supra, at 662. See also (1933) 43 YaLE L. J. 171-280 for a symposium on the Securities Act.

2 This paper was originally undertaken as part of a joint project in cooperation with Professor E. Merrick Dodd, Jr., of the Harvard Law School. Professor Dodd's section was to deal with the legal status of the promoter prior to the passage of the Securities Act of 1933. The section lere printed was written by the author in order to illustrate the application of the Securities Act of 1933 to the problems of promotion. The scope of this paper is restricted to the procedure of the Securities and Exchange Commission, and the discussion of a few selected cases to illustrate the effect of the Act and its administration on the problems of promotion. The advice and assistance of Professor Dodd during the time this paper was part of a joint enterprise are gratefully acknowledged. It should be emphasized that this paper is intended to call attention to an aspect of the activities of the Securities and Exchange Commission which has not been generally noted. For critical analysis of the Act as a whole, see the references in note 1, supra.

3 "Colnmission" herein refers to the Securities and Exchange Commission. 
mation from the date of filing. In order that the Commission and the public may have an opportunity to examine the statement before the securities are put on the market, it does not become effective until twenty days have elapsed.

The statements are filed on various forms ${ }^{4}$ promulgated by the Commission. Form A-1 is designed for new enterprises, and it is this form on which promotional ventures are registered. The items required to be answered are designed to elicit information which will adequately reveal the character of the promoters, the nature of the promotional process and the amount of compensation to be received directly or indirectly by promoters. The first group of items calls for infornation about the past history of the promoters, such as whether any state commission has denied them the right to sell securities. Secondly, a series of items requires information concerning options, ${ }^{5}$ the stock distribution contemplated, the underwriting contract, the nature of any property purchase to be made with the proceeds, and the balance sheet and income statement ${ }^{6}$-all these serving to bring out the essential facts. Furthermore, the compensation of officers and promoters, direct or indirect, through salaries, price discounts, commissions, or bonuses, inust be clearly revealed. Much of this is information which in the past has rarely been vouchsafed to the public. An investor ${ }^{7}$ receiving a prospectus based on these items will have more facts available for an informed judgment than were normally revealed to him prior to the enactment of the Securities Act.

The Securities Act attempts to make it reasonably certain that all of these items will be fully and correctly answered by inposing civil liabilities, and under certain circumstances, criminal penalties, for incomplete, untrue or misleading answers. In addition-and here is where the activities of the Securities and Exchange Commission come inthe Act provides a preventive remedy. This sanction empowers the Commission to issue an order refusing to permit the registration to become effective or suspending an effective registration if it appears that the statement contains a material falsehood or oinits something which the statute requires to be stated or which needs to be divulged in order

4 Specimens of the various forms may be obtained by writing the Publications Unit, Securities and Exchange Commission, Washington, D. C.

5 Options held by promoters, underwriters, etc.

6 The balance sheet and income statement of new enterprises are of less utility than similar statements of established enterprises. See Smith, Balance Sheets of Promotional Enterprises (1935) 60 Tre JourNat of Accountancy 198.

7 While the average investor may not benefit in every case from the complicated data called for by the Securities Act, investment counsel, and other investment experts, make use of this additional information, and thereby indirectly benefit the investor as well as affect the market reaction to the security. 
to prevent the statement from being misleading. ${ }^{8}$ Can the Commission discover misrepresentations and concealments promptly enough to prevent the marketing of the securities until the truth about them has been told? The whole problem of compelling promoters to disgorge profits which they have obtained by falsehoods and concealments has plagued the courts ever since the era of corporate promotion began. The courts have always been faced with an accomplished promotion. The Commission, if successful, would have made great strides toward solving this problem by compelling disclosure before security selling can begin.

The solution of the problem of compelling disclosure does not depend alone on the existence of legal remedies. Such remedies are not self-operating. The caliber of the personnel and the methods by which their efforts are organized will largely determine the success of the Commission. The comprehension of these methods calls for a brief sketch of the organization.9

The "Registration Division" is the internal administrative unit charged with the examination of registration statements. This division has in turn been subdivided into groups. Each group, consisting of seven to ten persons, is headed by a Securities-analyst, a man experienced in the analysis of securities, who supervises the work. Each Securitiesanalyst is assisted by an attorney, an accountant, and by several "examiners." The men selected as examiners have had experience in security analysis. The entire division is under the supervision of the Director. The Director is also aided by three Assistant Directors, and by special assistants in accounting, petroleum engineering, and mining engineering. When a registration statement is filed, it is then referred to one of

8 Section 8, SECURITIES ACT of 1933, supra note 1.

9 This description of the procedure does not take account of any changes thercin necessitated by the decision in Jones v. Securities and Exchange Commission, sttpra note 1 . The scope of that decision centered on the validity of the application of the rule contained in Release No. 47, now Rule 960 of the General Rules and Regulations, which required the Commission to find a withdrawal by the registrant to be "consistent with the public interest and the protection of investors." In that case, the Supreme Court leeld that when the statement was not effective, the registrant had an absolute right to withdraw, reasoning by analogy from the general rule at coinmon law and equity that, unless there exists a rule of court to the contrary, the plaintiff may dismiss, prior to verdict or decree, as of right "unless the dismissal would legally prejudice the defendants in some other way than by future litigation of the same kind." The Commission's rule was construed not to restrict the general, law or equity principle. Whatever the merits of the particular case, it seems unfortunate that the court should bold procedural rules of private law to be controlling. The proper balance between administrative discretion and the rule of law is a problem pressing for clarification. The Jones case, it is submitted, is of no assistance in solving the problem. For an application of the decision in the Jones case to an attempted withdrawal under Rule 960 , when the statement lacd become effective, see "In the Matter of National Boston Montana Mimes Corporation," Release No. 970, SECuRIties ACT of 1933 (August 10, 1936). 
these groups for examination, the reference depending on the type of enterprise and the burden of work of the group at the time. The Securities-analyst assigns the statement and the prospectus based on it to one of the examiners, who checks them, item by item, with the form and the rules and regulations of the Commission to ascertain whether the registrant ${ }^{10}$ has answered the questions fully and in such a way as to give a fair picture of the security. The examiner prepares a preliminary report analyzing the security and stating any deficiencies ${ }^{11}$ found in the course of examining the statement.

The accountant for the group studies the financial reports submitted as part of the statement to determine their compliance with the regulations as well as their adequacy in presenting the financial situation of the issuer. The attorney serves as adviser on any question raised by the group, including the question of the materiality of any misstatement or omission in addition to the statement's compliance with formal legal requirements.

Independently of the procedure described above, every prospectus is examined by a separate group of accountants who thus serve as an additional check to make sure that the investor will get a fair picture of the security. If the securities being registered present technical probleins in the fields of appraisal, mining engineering, or petroleum engineering, specialists available for all groups will examine the statement with an expert's eye. Furthermore, in cases where a clear picture of the security cannot be derived from an intensive study of the statement and attendant documents, a field investigation will be ordered. Frequently, these investigations have revealed facts that present a situation to the investor quite different from the disclosures made in the statement originally filed. These further investigations are also suggested by another weapon in the Commission's arsenal. The complaint section of the Legal Division, in cooperation with state and city security regulatory authorities, maintains an extensive file on fraudulent promoters. The appearance of the name of one of these gentlemen on a statement warrants investigation when the statement itself may not suggest it.

Descriptions of procedure too often obscure the realities. The various examinations of the statement are not mechanical checks of formal requirements by bureaucratic Frankenstems. They rather represent analysis enlightened by experience in the securities field. Frequently the experts sense that the security offered is a "phoney," and further study often reveals a fraudulent scheme. These men are familiar with

10 Registrant is the term for the issuer of the securities being registered.

${ }^{11} \mathrm{~A}$ deficiency is a misstatement or omission of a material fact. 
other sources of information which aid in detecting frauds. The benefit of their combined experience transforms the procedural forms into effective admmistrative devices.

Upon completion of the preliminary analysis, the group meets for discussion of the examiner's report. If the examination has revealed no deficiencies, and there is no indication that field investigation would disclose a different picture, the statement is recommended for clearance, sent to the Assistant Director, and, if cleared by him, becomes effective at the end of twenty days. If, however, the examination discloses any deficiencies, they are discussed by the group in conference, and those considered material are embodied in a tentative Letter of Deficiencies. This Letter of Deficiencies is checked by an Assistant Director, who, if he is in accord, signs it and it is mailed to the registrant by the tenth day after the filing. If a point not previously decided is raised, then the Director will pass on it before the Letter of Deficiencies is sent out. In novel and important situations, the Commission will settle the lines of policy to be followed.

The Letter of Deficiencies is accompanied by a notice stating that amendments in accordance with the Letter should be filed. If the amendments, exammed in the same way as the original statement, meet the objections raised and no new deficiencies appear in the light of the new information, the statement will become effective. Each new amendment creates a new filing date, starting a new period of twenty days which must run before the statement can take effect, unless the Commission consents to the filing of the amendment as part of the original statement. ${ }^{12}$ In most cases this consent is given so that the amending process does not interfere with the statement's becoming effective at the end of the twenty-day period. However, where deficiencies are serious and no real effort to meet the difficulties is made, subsequent Letters of Deficiencies and subsequent amendments will extend the process over a longer time. This administrative process does, however, permit the registrant to avoid the issuance of a refusal-order, ${ }^{13}$ the sanction given the Commission to prevent a deficient statement from being effective. In cases where there is little hope of administrative correction, the Commission will send no Letter of Deficiencies but will give notice of a refusal-order, to which the issuer usually consents.

Statements which have become effective may, upon the basis of later information, appear to contain material misstatements or omissions. The Commission im such cases may, and in most cases will, serve notice of stop-order ${ }^{14}$ proceedings on the registrant. The stop-order is the sanc-

12 Section 8 (a), Securities Act, supra note 1.

13 Section 8 (b) ibid.

${ }^{14}$ Section 8 (d) ibid. 
tion available for suspending the effectiveness of the statements which, although declared effective, now appear materially deficient. The stoporder notice names the iteins alleged to be deficient, and the date for the hearing of the evidence of the alleged inaterial deficiencies, at which time the registrant may introduce evidence in rebuttal. Hearings ${ }^{15}$ are usually held before trial examiners appointed by the Coinmission, and the Commission is represented by the lawyer attached to the group that examined the statement upon its filing. The Commission itself may hear the case, and, on written request of any party, a case previously heard before a trial examiner will be set down for oral arguinent before the Cominission. If oral argument before the Commission is not requested, which is the typical case, the trial examiner, within ten days after receipt of the transcript of the testimony, will make a report containing his findings of fact, which are advisory only and do not bind the Commission. The parties may file exceptions to the trial exaniner's report, as well as briefs in support of their respective contentions, and reply briefs confined to the original briefs. The Commission, in the absence of a request for oral arguinent, will pass on the record, the trial examiner's report, the exceptions and the briefs, and then rule as to the existence of material deficiencies calling for the issuance of a stop-order. In many cases, upon the introduction of evidence of deficiencies by the Cornmission, the registrant will consent to the entry of a stop-order, thus closing the proceedings.

Whenever the public interest dictates the desirability of calling public attention to the deficiencies found and to the promotional inethods disclosed, the Coinmission will write an opinion, and thus publicize its findings. This is true whether the registrant has consented to the issuance of a stop-order or not. The published opinions of the Commission, viewed as a whole, present a picture of new frontiers in the protection of the investing public. While many of the cases expose unusual promotional devices of interest to the connoisseur in promoter's frauds, the cases of most value to the public are those wherein inethods frequently and successfully employed by promoters in the past have been checked by the new standards promulgated by the Securities and Exchange Commission in its administration of the Securities Act.

\section{III}

The most typical promotion situation is presented when a promoter has acquired property at a nominal price which he turns over to a corporation in exchange for a large block of stock which is resold to the

15 First Annual Report of the Securities Exchange Commission, Appendix II. Rules of Practice, Securities and Exchange Commission, effective September 13, 1935. These rules of practice are applicable to proceedings under the SEcorITIES Exchange ACT of 1934. 
public on the basis of the valuation made by the promoter-controlled corporation. While there are infinite variations from this basic formula, the valuation of the assets is the focal point of attack in these cases. The Commission's action in the case of Haddam Distillers Corporation ${ }^{\mathbf{1 0}}$ demonstrates the potentialities of the stop-order as a technique for curbing overvaluation.

The promoters acquired at Moodus, Connecticut, the equipment, processes, and plant site for a distillery business. On August 31, 1933 they incorporated a company, later known as the Haddam Distillers Corporation, under the name of the Premier Distillers Corporation. They set it up with an authorized capital stock consisting of 330,000 shares of Class A stock, preferential nonvoting shares, and 20,000 shares of Class B voting stock. Both classes had a par value of $\$ 5$ per share. The promoters then turned over the assets to their corporation in exchange for $\$ 250,000$ in stock, comprising all the Class B voting stock and 30,000 shares of Class A stock. They intended to resell the Class A stock to the public at varying prices.

Whether the property had been overvalued, with consequent "watering" of the stock, depended on the valuation of the assets made for the corporation by the Standard Appraisal Company of New York. It is this appraisal which the Commission attacked as false, and the balance sheet, based on the appraisal, was likewise challenged. Deficiencies in the statement originally filed were not found to have been satisfactorily corrected either by amendments or by conferences between the officers of the corporation and officials of the Commission. The corporation then attempted to withdraw its first statement, and filed another, which was also found unsatisfactory. The valuation engineer of the Commission visited the plant site and inspected buildings and equipment, finding the valuations excessive and descriptions inadequate. Stop-order proceedings were thereupon instituted.

The testimony adduced at the liearing led the Commission to characterize the appraisal as irresponsible. The garage, listed as a "two story, basement, vertical sided frame building of simple construction," turned out to be a barn with the second floor accessible only by means of a four-foot-square opening, and the first floor incapable of supporting the large trucks of the corporation. The appraisal of the water supply was similarly marked by a flagrant disregard of the factors relevant to a scientific valuation. A figure of $\$ 70,120$ for the general service water supply coming from the Moodus River, a creek 10 feet wide and 8 to 18 inches deep, was based on esoteric methods such as computing the flow of the stream by timing the flow of a potato for a hundred feet!

16 In the Matter of Haddam Distillers Corporation (1934) 1 S.E. C. 37. 
Although the appraisal contract called for an independent appraisal, much of the equipment was never inspected by the appraiser, and for the equipment that was imspected no bona fide attempt was made to follow the reputed norm of "reproduction cost new," and "depreciated or sound value." Thus, a "distillery unit" was listed at $\$ 125,000$, despite the statement of the corporation's vice-president that the total cost, five years before, was $\$ 40,000$, and the fact that the present cost price could have been easily ascertained. Similar laxness was evident in all the equipment valuations. No effort to consult standard price lists was made. The testimony of the corporation's vice-president suns up the true nature of the appraising.

"Counsel for Commission: As a matter of fact, isn't this what has been tacked on to the various elements in this deal, the promoters' profits and compensation, and instead of issuing stock directly to the promoters for their services for promotion, you tacked it into machinery and equipment .... ?"

"The vice-president: That is the way it appears."17

Upon the conclusion of the hearing on the stop-order, the corporation submitted further amendments alleged to cure the deficiencies, including a new appraisal by a different company. In refusing to exercise its discretion to consider the new situation, the Commission in its opinion ${ }^{18}$ stated:

"But the circumstances attendant upon the present case clearly give no warrant to the Commission to exercise its discretion in order to permit the registrant to escape the consequences of a neglect and folly that approaches fraud. Trustee-ship of other people's money, which the registrant in offering its securities to the public seeks to assume, demands under the present Congressional mandate embodied in the Securities Act some warrant of open, fair, and careful dealing. The registrant has twice failed to meet that criterion. Now that the deficiencies have been called forcibly to its attention, it hopes by curmg them to regam its right to sell securities. But it should certainly not acquire that right under these circunstances when this Commission has the power to transmit generally to the public this evidence of the registrant's disregard of fundamental business ethics and this evidence of unconscionable pretense of scientific method by an appraisal company. A nation of investors deserves, at least, this slight protection."

Following the issuance of the stop-order, and the publication of this opinion, the corporation filed a series of amendinents designed to cure the deficiencies. While the Commission refused at that time to lift the stop-order upon the basis of these amendinents because of a new deficiency arising out of an accounting method, ${ }^{19}$ the new property valuations then submitted were not challenged as deficient. These new valuations included reappraisals of water rights and equipment in order to make the balance sheet a fair representation to the investor. The revalua-

17 File Nos. 2-880, 2-993, Securities Exchange Commission.

18 Supra note 16 , at 47 .

19 (1934) 1 S.E. C. 48. 
tion of the water rights is the most striking instance of the changes made. An origimal valuation of $\$ 97,120.00$ was reduced to the nominal figure of $\$ 1.00$. The fixed assets as a whole were reduced $66 \%$, or from $\$ 312,090.00$ to $\$ 104,996.02$. This difference of $\$ 207,093.98$ was in essence "water." This deflation had happy repercussions in the reduction of the amount of stock assigned to the promoters from $\$ 250,000$ to $\$ 104,500,40 \%$ of their original allotment. These reduced valuations were the ones presented to the investor when the Commission, finding all deficiencies corrected, declared the statement effective. These reductions of the property valuations and of the compensation of the promoters bear eloquent testi- . mony to the preventive virtue of administration.

\section{IV}

The effectiveness of this process in curbing over-valuation is further illustrated by the Unity Gold case. ${ }^{20}$ Here again the valuation of property exchanged for stock formed the crucial problem. But in place of simple misdescription and over-valuation, as in the Haddam case, ${ }^{21}$ the techniques employed by the Unity Gold promoters raised more subtle questions as to the ambit of the stop-order.

J. L. King acquired an option and lease on mining property for a consideration of $\$ 1$, plus the obligation to operate the property and pay royalties. This lease and option were transferred to a corporation which he organized in exchange for the entire capital stock, 2,000 shares of $\$ 1$ par value. Expenditures of $\$ 5,000$ failing to produce results, King sought more capital. Maxwell headed a group of promoters who organized in Colorado the Unity Gold Corporation to acquire the assets of King's corporation. The lease and option belonging to King's corporation were assigned to the Unity Gold Corporation for $\$ 5,000$ and 599,995 shares of the latter's common capital stock of the par value of $\$ 1$ per share. The contract of transfer stipulated that King's corporation was immediately to "donate" back to Unity Gold's treasury 475,000 of these shares. The purpose of this provision in the contract was to create valid treasury shares which could then be sold to the public at less than par as non-assessable stock. These shares were included on the balance sheet as part of the cost of the property. The promoters insisted that these shares were issued for value despite the simultaneous "donation" back to Unity Gold's treasury. Their insistence was based on court decisions. The courts of many states, including Colorado, where this corporation was organized, have held such an arrangement to be a legal method of creating non-assessable stock. Other jurisdictions have regarded such a method as presumptive evidence of gross over-valuation

20 In the Matter of Unity Gold Corporation (1934) 1 S. E. C. 25.

21 Supra note 16. 
and the stock therefore not fully paid. ${ }^{22}$ Counsel for the Commission, claiming that the concurrent "donation" demonstrated the fictitious character of the original issue, challenged the inclusion of such stock as part of the cost of the property.

Although the validity of the issuance of the remaining shares was also challenged, the legality under the standards of the Securities Act of this concurrent "donation" was the principal question in the case. The Commission, in deciding this question, held the balance sheet entry of such donations as part of the cost of property to be "untrue and misleading under the standards of truthfulness demanded by the Securities Act," whatever the courts of any state might rule in creditors' suits based on a charge of watered stock. Security promoters intending to use the "donated" stock method for compensating themselves will henceforth be barred from interstate sales of their wares. Most promoters seek a market broader than a single state. The stop-order has therefore served as an indirect method of creating new law on the validity of this method of financing.

\section{$\mathrm{V}$}

Enterprises which ask the investor to entrust his savings to the financial wisdom and integrity of the promoter-managers represent ventures of the greatest importance to the investing public. The National Educators case $^{23}$ illustrates the value of forcing those handling other people's money to disclose all the conditions of the fiduciary trusteeship ${ }^{24}$

22 Dodd, Stockwatering (1930) 260, 261.

23 In the Matter of National Educators Mutual Association, Inc. (1935) 1 S.E. C. 208.

24 The remarks of Mr. Justice Stone at the dedication of the University of Michigan Law Quadrangle are significant: "I venture to assert that when the history of the financial era which has just drawn to a close comes to be written, most of its mistakes and its major faults will be ascribed to the failure to observe the fiduciary principle, the precept as old as holy writ, that 'a man cannot serve two masters.' More than a century ago equity gave a hospitable reception to that primciple and the common law was not slow to follow in giving it recognition. No thinking man can believe that an economy built upon a business foundation can permanently endure without some loyalty to that principle. The separation of ownership from management, the development of the corporate structure so as to vest in small groups control over the resources of great numbers of small and uninformed investors, make imperative a fresh and active devotion to that principle if the modern world of busmess is to perform its proper function. Yet those who serve nominally as trustees, but relieved by clever legal devices, from the obligation to protect those whose interests they purport to represent, corporate officers and directors who award to themselves huge bonuses from corporate funds without the assent or even the knowledge of their stockholders, reorganization comnnittees created to serve interests of others than those whose securities they control, financial institutions which, in the infinite variety of their operations, consider only last, if at all, the interests of those whose funds they command, suggest how far we have ignored the necessary implications of that principle. The loss and suffering inflicted on individuals, the harm done to a social order reared upon a business base and dependent upon its integrity, are incalculable." Reprinted, Stone, The Public Influence of the Bar (1934) 48 HARv. L. REv. 1, at 8. 
which they undertake. The registration statement filed in that case became effective, but subsequently the Commission, charging material deficiencies, instituted stop-order proceedings. At the hearing, the corporation consented to the entry of a stop-order, and admitted by a written stipulation the deficiencies charged as well as the existence of other deficiencies. Despite the consent and admission, the nature of the case, "m essence an enterprise to deal in an irresponsible fashion with the small savings of city and county school teachers," led the Commission to make findings and write an opinion to publicize the methods employed.

The most glaring deficiency in this case was the corporation's concealment of its unsuccessful operation prior to the current offering of its securities. A brief sketch will serve to show the nature of its previous operations and the method by which the promoters attempted to avoid the reaction of the investor to such a financial record.

The chief promoter was Charles G. Pfab, who became its executive vice president. The corporation was organized October 31, 1932, in Tennessee, with an authorized capital stock of 25,000 shares of no-par common, "12,000 shares of which have been issued and are outstanding, being paid in at the price of 10 cents a share." Pfab was the beneficial owner of 68 per cent of these shares. From the time of its organization until the decision to expand the business into other states, the corporation had been soliciting subscriptions for so-called Endowment Bonds, sold in units described as " 5 annual payment 12-year Endowment Bond with 5 shares Bonus stock." These shares of no-par common stock were alleged to have a "stated" value of $\$ 50$, despite the fact that the promoters had paid ten cents a share for shares of the same class. These gentlemen, at the time of the hearing, had obtained nearly a thousand subscriptions froin Tennessee residents.

On April 30, 1935, the date of the balance sheet in the registration statement, the corporation had received $\$ 53,272.61$ on account of these subscriptions, 70 per cent of which, or $\$ 35,943.58$, had been spent for "sales expense". During this period, the auditor of the corporation's books states: "The income from operations for the two and one-half years of the corporation's existence has been nominal ... This income has not been sufficient to cover the minimum amount of operating expenses. The sales agent has contributed annually from his commission earnings to offset the deficit in operations. These amounts have been reported as other income." For the purpose of making an unhappy venture more palatable, these donations by Pfab, who acted as sales agent, were treated as income. The promoters admitted that except for this claimed income, there would have been a net loss shown. 
In its opinion the Commission writes: ${ }^{25}$

\begin{abstract}
"Sound accounting theory and practice require that no income could be considered as having been realized by reason of the contributions, and accordingly, the amount of same should not have appeared in the profit and loss statement at all. . . As we have had occasion to state before, 'We deem it very important that earnings should not be inisrepresented.' ... In substance there was nothing more than a cancellation of an indebtedness, which even for income-tax purposes is not regarded as income. Including it as such was highly misleading."
\end{abstract}

This drab record of earnings left the promoters unabashed. A further comparison of the registration statement with the facts revealed at the subsequent hearing shows that not only was the income account distorted, but that the description of the so-called bond was completely misleading. Each unit was described by the promoters as "a 5 annual payment 10-year Endowment Bond with 5 shares Bonus stock." These bonds, for which the investor was to pay $\$ 750$ in five installments of $\$ 150$ each, were further described as $\$ 1,000$ bonds, thereby giving the impression that the investor would receive a high rate of interest on his money at the end of the ten years when the bonds fell due. It was only by a careful reading of the registration statement that the investor would discover that instead of being promised $\$ 1,000$ he was merely entitled to the ultimate return of his $\$ 750$ without interest, and in addition the receipt of five shares of the corporation's stock. Although this stock was given a "stated" value of $\$ 50$ a share, it was the same stock for which the promoters had paid ten cents a share and represented an interest in an enterprise which had thus far been operating at a loss. To label a promise to pay $\$ 750$ in cash and the balance in stock of this character, a $\$ 1,000$ bond was obviously misleading. Likewise the contract attached to the bond set up a "Guaranteed Cash Surrender Value" for every year after the first, and in each instance the amount proclaimed in large letters consisted, in fine print, largely of this stock. Thus $\$ 313.60$, the sum which was listed as the cash surrender value at the end of the second year, in reality was composed of $\$ 63.60$ in cash, and five shares of stock, for which the investor had exchanged $\$ 300.00$ in cash. A presentation of this character would scarcely inform the investor of the true nature of the contract.

A third type of misrepresentation was the attempt to create a false impression of educational mutuality. As further bait for the credulous investor, the corporation's prospectus prominently displayed on its first page the names and titles of numerous educators in Tennessee. The very name of the corporation, National Educators Mutual Association, Inc., was admitted to be misleading, both in its emphasis on a mutuality which was wholly lacking in this profit-seeking venture and in its sug-

25 Supra note 23, at 213. 
gestion of a professional association of educators known as the National Educators Association.

The Commission summed up the enterprise thus seeking the use of other people's money: ${ }^{26}$

"The general statement of the nature of this particular enterprise . . . is obviously far from the fact. The cynically minded might well read certain paragraphs of this statement as indicating that educators or school teachers are unused to financial transactions and thus reach the conclusion which seems to be the hope of this enterprise that they are easily duped. But it is the avowed belief of the gentlemen who conduct this enterprise that the school teachers to whoin they are proposing to sell these 'bonds' have little knowledge of the niceties of finance and imvestinent. How much more reprehensible does their conduct then becone in the light of such a belief! How much more important does it then devolve upon them to state frankly that they are in essence asking school teachers to put their savings in their control and for their management of these savings these school teachers are to give thein more than half of the profits that may enure to the enterprise. For, in essence, in this 'mutual' enterprise profits go to promoters and advisers in the ratio of approximately 60 per cent and to the investing 'bondholders' in the ratio of approximately 40 per cent! No array of locally prominent naines should be permitted to conceal these facts; nor, we hope, will any future prospect be left unaware of the danger of entrusting the small savings derived froin school teaching in the hands of men who upon this record and by their own adinission have demonstrated untruthfulness and misfeasance im positions of trust and confidence."

\section{VI}

The value of forcing disclosure of the facts of promotion could be adumbrated by other cases. But these selected instances sufficiently emphasize the merits of preventive action in contrast to the ineffectiveness of the traditional remedies - an ineffectiveness ${ }^{27}$ which was instrumental in creating public demand for the passage of the Securities Act. Inevitably the success of the act will be measured in large part by the efficacy of its additional remedies in protecting the investor.

Within the realm of interstate commerce and the mails, the Commission has set new standards,--standards which may well revolutionize the whole process of corporate promotion. ${ }^{28}$ Promoter's services are no longer concealed, but are openly disclosed as such. The investor may weigh their worth before becoming a partner in the enterprise. Furtherinore, the issuance of stop-orders by the Commission serves to protect the investor from the more unconscionable methods of obtaining his savings. The actual experience of administering the statute has shown that these orders have been a stronger weapon for deterring promoters

26 Supra note 23 , at 215.

27 See James, The Securities Act of 1933 (1934) 32 Micr. L. Rev. 624; Ashby, Federal Regulation of Securities Sales (1923) 22 Irr. L. REv. 635; Washburn, Control of Securities Selling (1933) 31 Micm. L. Rev. 768; Steig, What Can the Regulatory Securities Act Accomplish? (1933) 31 Micr. L. Rev. 775.

28 See Note (1936) 49 HaRv. L. Rev. 785. 
than the in terrorem aspects of the civil liability provisions..$^{29}$ The vexing problem of compensating promoters would seem to be approaching an equitable solution. It is true that, as the cases discussed indicate, the promotion schemes with which the Commission has dealt up to date have been relatively small affairs. The revival of business has not yet progressed to a point which makes the promotion of new large-scale enterprises practicable, ${ }^{30}$ and accordingly no such promotions have come before the Commission. But the technique which the Commission has evolved can be applied as readily to an industrial giant as to a hundred-thousand-dollar distillery.

This discussion of the effects of the Commission's enforcement of the Securities Act with respect to promoter's profits should not obscure the broader aspects of the task imposed on the Commission by the administration of that Act, as well as by the Securities Exchange Act of $1934^{31}$ and the Public Utility Act of $1935 .^{32}$ Only one phase of the general problem of inaugurating a program of social control of finance has been considered. Control of seasoned corporations suggests problems impossible to include here. ${ }^{33}$ But within the field of promoter's frauds, the Commission has succeeded in protecting the savings of large groups of people who were formerly unable as a practical matter to get adequate protection under state laws. ${ }^{34}$ This success fully justifies the extension of federal control necessary to accomplish this desirable protection of savings.

Brunson MacChesney.

SCHOOL OF JURISPRUDENCE, UNIVERSITY OF CALIFORNIA.

29 See the prediction to this effect of Professor Rodell. Rodell, Regulation of Securities by the Federal Trade Commission (1933) 43 Yale L. J. 272.

30 August and September, 1936, have, however, revealed a sharp increase in the relative proportion of the proceeds of registrations devoted to new financing.

3148 Stat. (1934) 881, 15 U.S. C.A., § 78a ff. (Supp., 1935).

3249 STAT. (1935) 838, 15 U.S. C.A., \& 79 ff. (Supp., 1935).

33 See Berlack, Federal Incorporation and Securities Regulation (1936) 49 HaRv. L. REv. 396; Stevens, Uniform Corporation Laws Through Interstate Compacts and Federal Legislation (1936) 34 MicH. L. Rev. 1063. For a discussion of the problems raised by the co-existence of the "Blue Sky" Laws and the Federal Securities Act, see Smith, State "Blue-Sky" Laws and the Federal Securities Act (1936) 34 Mich. L. REv. 1135.

34. "The more stringent of these laws inake it illegal to market an issue of securities in the state until an administrative commission has licensed the sale, and some of the state commissions have attained a considerable degree of success in forcing the abandonment of promotion schemes under which the public is financing the promoter rather than the enterprise in which its money is being ostensibly invested. Even the states in which the law is most drastic and inost effectively admimistered have, however, been unable to prevent promoters from imcorporating in some other state which has an ineffective blue-sky law or none at all, and then selling their securities in the state which has more stringent laws through the use of devices which make it practically impossible for the commission in the latter state to prevent the sale or penalize the sellers." (This is taken from a section written by Professor E. M. Dodd, Jr.). See references in note 27 , supra. 